\title{
PINE BARK BEETLE AND DWARF MISTLETOE INFESTATION IN A REMNANT OLD-GROWTH STAND
}

\author{
Nicholas Aflitto ${ }^{1}$, Tom DeGomez ${ }^{1,5}$, Richard Hofstetter ${ }^{2}$, John Anhold ${ }^{3}$, \\ Joel McMillin ${ }^{4}$, Mike Wagner ${ }^{2}$, and Eryn Schneider ${ }^{2}$
}

\begin{abstract}
Aвstract.-We examined the incidence of bark beetle (Coleoptera: Curculionidae: Scolytinae) colonization and subsequent mortality, and the presence of dwarf mistletoe (Arceuthobium vaginatum subsp. crytopodum) within a rare remnant old-growth stand of ponderosa pine. In 2011, 96\% of the old growth trees were remaining with additional dense ingrowth of ponderosa pine (Pinus ponderosa Douglas ex. Lawson) within the understory of the oldest trees. We compared the old-growth stand to abutting stands of ponderosa pine: a low-density seed-tree cut and a high-density post-1900 second growth. The old-growth stand had levels of bark beetle colonization similar to the seed-tree stand, and both of these stands had significantly more bark beetles than the high-density stand. Across all sites, bark beetles were found in higher numbers in the $51-60 \mathrm{~cm}$ diameter class. We found a trend between the proportion of trees infected per site and the percentage of trees with bark beetle activity, although a direct relationship between a tree's dwarf mistletoe infection and beetle attack was not found. This work indicates that large, older trees are not immune to endemic bark beetle attack and subsequent mortality. In light of current efforts to implement forest restoration practices that favor older and larger trees, managers of ponderosa pine forests should be aware that risk from bark beetle attack may increase as basal area increases within the stand.
\end{abstract}

Resumen.-Examinamos la incidencia de la colonización de escarabajos de corteza (Coleoptera: Curculionidae: Scolytinae) y su mortalidad subsecuente, así como la presencia de muérdago enano (Arceuthobium vaginatum subsp. crytopodum) dentro de un remanente raro de pinos maduros (Pinus ponderosa). En el 2011, el 96\% de los árboles maduros aún permanecía ahí con un crecimiento interno denso de pino ponderosa (Pinus ponderosa Douglas ex. Lawson) en el sotobosque de árboles más viejos. Comparamos la zona de árboles maduros con zonas colindantes de pino ponderosa, con una zona de baja densidad de árboles por tala selectiva, y con una zona de alta densidad de crecimiento secundario posterior a 1900. La zona de árboles maduros tuvo niveles similares de colonización de escarabajos de corteza que la zona de tala selectiva, y la colonización en estas dos zonas fue significativamente más elevada que en la zona de alta densidad. En todos los sitios, los escarabajos de corteza se encontraron en mayor número en árboles con diámetro de 51-60 cm. Encontramos una relación entre la proporción de árboles infectados por sitio y el porcentaje de árboles con actividad de escarabajos de corteza, aunque detectamos una relación directa entre la infección del muérdago enano y el ataque del escarabajo. Este trabajo indica que los árboles más altos y viejos no son inmunes al ataque del escarabajo de corteza endémico y a su consecuente mortalidad. En vista de los esfuerzos actuales para implementar prácticas de restauración forestal que favorezcan a los árboles más viejos y más altos, los gestores de los bosques de pino ponderosa deberán considerar que la relación entre la densidad de los árboles y la colonización de los escarabajos puede incrementar con el aumento de las zonas restauradas en áreas basales.

Management practices in the southwestern United States have greatly altered the structure of the ponderosa pine forest type (Pinus ponderosa Douglas ex. Lawson) (Covington and Moore 1994, Covington et al. 1997, Fulé at al. 1997). These changes have commonly resulted in a shift from an open park-like structure with large-diameter trees, to highstem-density forests with small-diameter trees (Covington et al. 1997, Dahms and Geils 1997). Although there are multiple factors contributing to these post-European settlement forest conditions, the fire exclusion, overgrazing, and logging are the leading causes (Madany and West 1983, Covington and Moore 1994, Brown and Sieg 1996, Allen et al. 2002, Moore et al. 2004, Zausen 2005). The high density of small-diameter trees not only increases the risk of stand-replacing crown fires but greatly alters insects and disease population dynamics (Covington and Moore 1994, Kolb et al. 1994, Stone 1999).

\footnotetext{
${ }^{1}$ University of Arizona, School of Natural Resources and Environment, NAU Box 15018, Flagstaff, AZ 86011.

$2^{2}$ Northern Arizona University, School of Forestry, NAU Box 15018, Flagstaff, AZ 86011

${ }^{3}$ USDA Forest Service, Southwestern Region, Forestry and Forest Health, Arizona Zone, 2500 S. Pine Knoll Drive, Flagstaff, AZ 86001.

${ }^{4}$ USDA Forest Service, Boise Field Office, Forestry and Forest Health, 1249 S. Vinnell Way, Suite 200, Boise, ID 83709.

${ }^{5}$ Corresponding author. E-mail: degomez@ag.arizona.edu
} 
Landscape-scale (large areas $>1000$ ha, comprising a mosaic of ecosystems/stand types) restoration projects would be required to return this ecosystem to historic conditions, and a greater understanding of past conditions is paramount to this endeavor (Fulé et al. 1997).

Numerous studies have been published quantifying the effects of tree density in southwestern ponderosa pine forests (Klemmedson 1976, Bailey and Covington 2002, Waltz et al. 2003, Wallin et al. 2004). However, there is a deficit of quantitative information on current forest conditions in presettlement ponderosa pine forests (Covington and Moore 1994), largely due to the rarity of unaltered stands in the region (Allen et al. 2002). According to Edmonds et al. (1999), extensive harvesting of the late 19th and 20th centuries have left approximately $10 \%$ of the original old-growth forests in the western United States. Understanding how disturbances function in old-growth ecosystems should be important to land managers attempting to transition toward historical conditions (Rasmussen at al. 1996, Santoro et al. 2001).

Bark beetles (Coleoptera: Curculionidae: Scolytinae) makeup a significant portion of the species diversity in forested ecosystems (Martikainen et al. 1999). They play an important role in forest dynamics, affecting forest succession (Roe and Amman 1970, Amman 1977, Stark 1982, Axelson et al. 2009), nutrient cycling (Goheen and Hansen 1993), and wildlife habitat and forage (Koplin 1969, ChanMcLeod 2006). Since several bark beetle species cause both small-scale and landscapescale disturbances, they are often considered keystone species (Amman 1977). In old-growth forest, bark beetles can shape many of the defining characteristics, such as structural diversity, presence of snags, and decomposition rates (Carpenter et al. 1988).

Southwestern dwarf mistletoe (Arceuthobium vaginatum subsp. crytopodum) is a common parasitic plant of ponderosa pine; a stressor that affects the growth potential and fiber production (utilitarian use) of the tree (Hawksworth 1961). This mistletoe is considered the most significant disease factor in southwestern ponderosa pine forests (Hawksworth 1961, Hawksworth and Wiens 1996). The effects of dwarf mistletoe infection are expressed through growth loss (Hawksworth 1961), increased mortality (Hawksworth et al.
1992), predisposition to other agents such as bark beetles (Kenaley et al. 2006), and the creation of fire hazards (Harrington and Hawksworth 1990). It is also important to note the ecological benefits of dwarf mistletoe, such as the role it plays in increasing species diversity and its numerous benefits to many wildlife species (Parks et al. 1999, Watson 2001).

Here we studied the presence of bark beetles and dwarf mistletoe in 3 adjacent ponderosa pine stands which experienced different management histories: (1) an unlogged site with large-diameter trees (known hereafter as Barney Springs; Fig. 1), (2) a seed-tree harvest, and (3) an untreated dense site with small-diameter trees. The objectives of the study were to (1) quantify the extent of bark beetle activity at the 3 sites and identify the bark beetle species present at Barney Springs, (2) quantify the severity and distribution of dwarf mistletoe, and (3) assess the utility of using the Barney Springs site as a predictor of future bark beetle-caused mortality and presence of dwarf mistletoe on sites that are slated for restoration treatment. The ultimate goal is to contribute to the limited information on how insects and diseases affect old-growth ponderosa pine forests in the southwest.

\section{Methods \\ Study Sites}

Three adjacent ponderosa pine stands were evaluated in this study located approximately $48 \mathrm{~km}$ southwest of Flagstaff, Arizona $\left(34.9891306^{\circ},-111.8050389^{\circ}\right.$; Fig. 2). All stands are nearly pure ponderosa pine, with a sparse intermixing of Gambel oak (Quercus gambelii Nutt) and white fir (Abies concolor Gord. \& Glend.). Data collection took place in August and September over a 3-year period, 2011-2013. Average annual precipitation (1986-2013) is $64.7 \mathrm{~cm}$ as reported from the Munds Park weather station, $16 \mathrm{~km}$ southeast of the study sites. Like most of the region, precipitation comes bimodally with half of the precipitation as summer rain and the other half as winter snowfall. Average temperature ranges from a minimum of -2 ${ }^{\circ} \mathrm{C}$ in winter to a maximum of $17^{\circ} \mathrm{C}$ in summer (Western Regional Climate Center 2013). Average elevation of the study area is $2097 \mathrm{~m}$ 


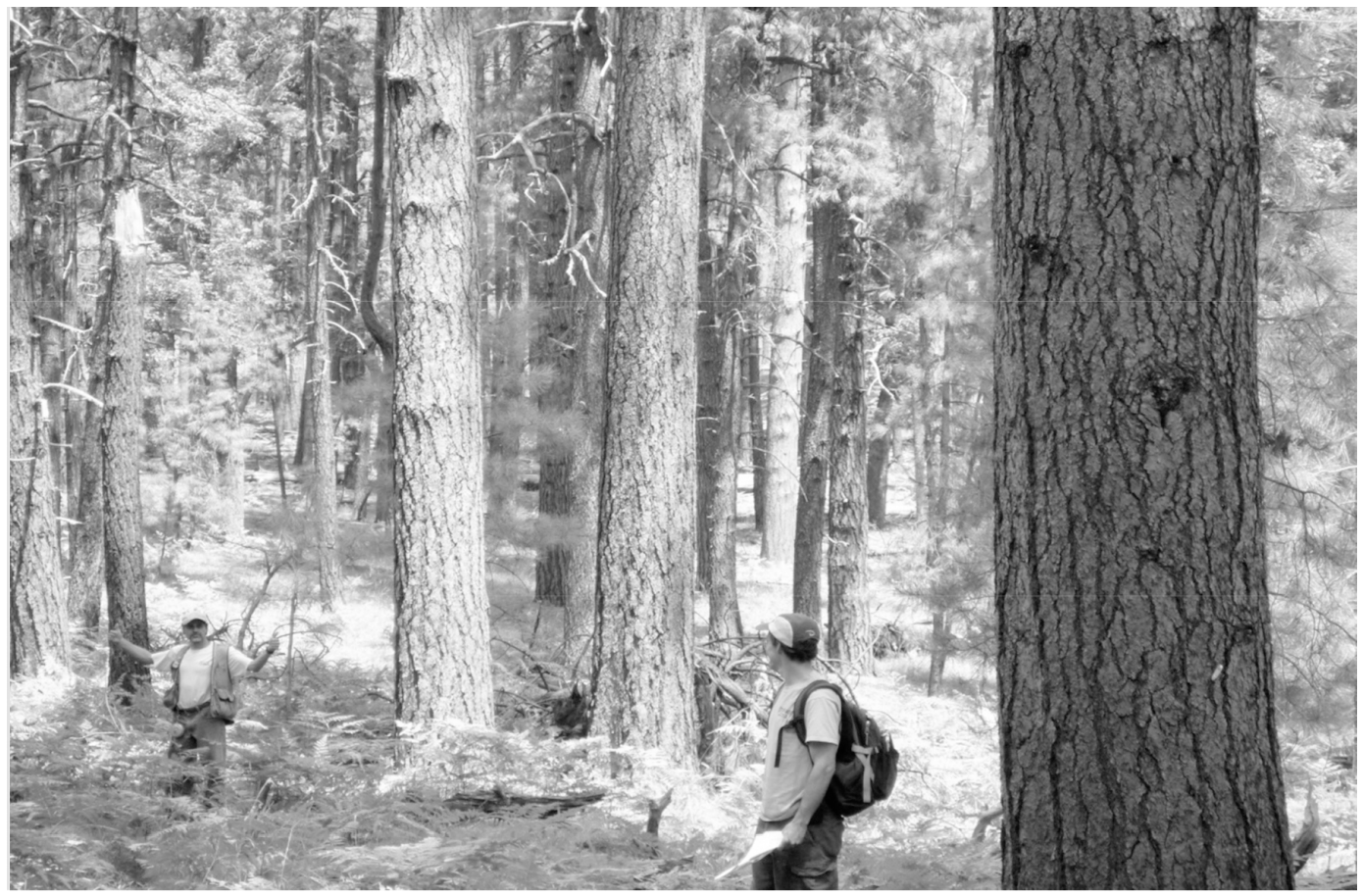

Fig. 1. Barney Springs site in 2012. Photo by Nicholas Aflitto.

\section{Three Study Sites}

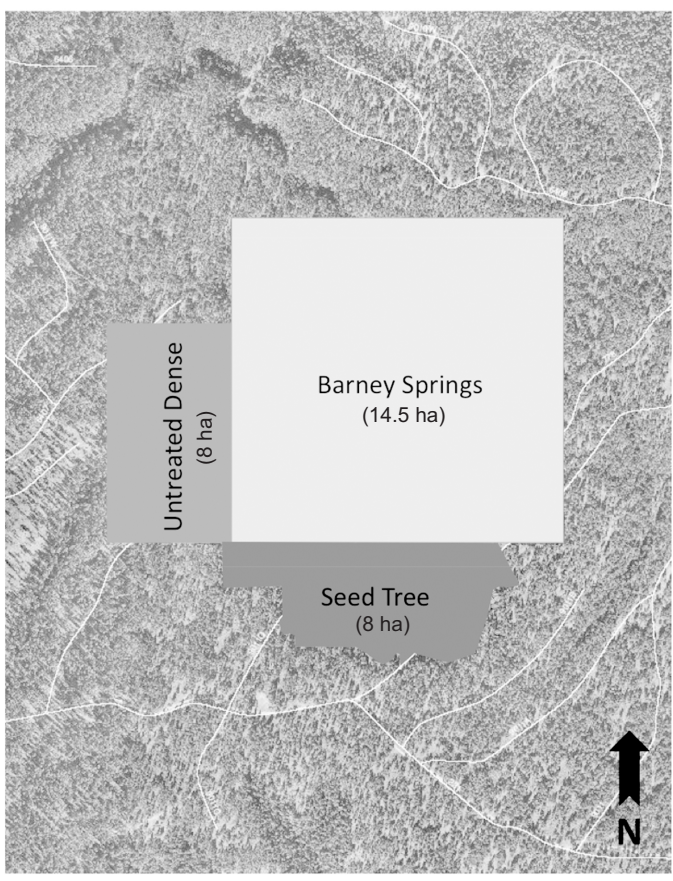

Fig. 2. The 3 study sites in northern Arizona. with nominal $(30-\mathrm{m})$ variation within the 3 stands (USDA Forest Service 1995).

STAND 1.-The Barney Springs site is the southern 14.5 ha of a 65 -ha privately owned quarter section which has not been commercially logged and as such contains numerous large (>60 $\mathrm{cm}$ diameter at breast height $[\mathrm{DBH}])$ ponderosa pine trees. The land was initially acquired from the federal government by the Santa Fe Railroad in the late 1800s and has since been sold to a private landowner. Up to $4 \%$ of the site has been cut, denoted by stumps (Schneider 2012). A stand containing a large number of trees that exceed $60 \mathrm{~cm} \mathrm{DBH}$ is unique. Equally unique is the number of large (41-60 cm DBH), younger $(<100$-yearold) trees growing in the understory of the larger $(>60 \mathrm{~cm} \mathrm{DBH})$, older (>100-year-old) trees. Also reported by Schneider (2012) is an interrupted fire regime and periodic livestock grazing at the site since European settlement.

STAND 2.-This area is an 8-ha stand managed by the USDA Forest Service in which a seed-tree cut was implemented in 1980 (a common practice in the region). Thirty-one years after the cut, very few ponderosa pine seedlings have become established. 
TABLE 1. Basal area, quadratic mean diameter (QMD), and trees per hectare (TPH) of each site. Standard errors are in parentheses. $n=$ hectare plots per site.

\begin{tabular}{lccrc}
\hline Site & Basal area $\left(\mathrm{m}^{2} \cdot \mathrm{ha}^{-1}\right)$ & QMD $(\mathrm{cm})$ & TPH & $n$ \\
\hline Barney Springs & $24.94(0.16)$ & $48.91(1.16)$ & 132 & 58 \\
Seed-tree & $10.43(0.13)$ & $45.09(3.04)$ & 76 & 29 \\
Untreated dense & $20.41(0.21)$ & $28.85(1.91)$ & 292 & 24 \\
\hline
\end{tabular}

STAND 3.-This area is an 8-ha untreated dense stand, also managed by the USDA Forest Service, which represents the most common ponderosa pine stand type in the watershed. The stand is dominated $(70 \%)$ by small (0-30 cm DBH), young (<100-year-old) trees.

\section{Sampling}

A previously established $50 \times 50$-m sampling grid was used to delineate the Barney Springs site (Schneider 2012). Plots $18 \mathrm{~m}$ in radius $(0.10 \mathrm{ha})$ were randomly installed: 58 in the Barney Springs site (centered in $50 \times$ 50 -m cell), 29 in the seed-tree cut site, and 24 in the untreated dense site. Overstory data such as diameter at breast height (DBH) and overall tree counts were previously measured in the Barney Springs site (Schneider 2012), and we recorded similar data for the seed-tree cut and untreated dense site. Each plot was inspected for the presence of bark beetles and southwestern dwarf mistletoe.

\section{Bark Beetle Assessment}

An insect attack rating (IAR) was assigned to each tree on a scale from 0 to 2 . A rating of 0 was given to trees with no sign of bark beetles, and ratings 1 or 2 were assigned to partial- (attack that has not caused mortality) or mass-attacked trees (mortality has occurred), respectively (following methods of McHugh et al. 2003). On beetle-attacked trees with $>75 \%$ crown fading (indicating that these trees were dead or soon to be dead), a $30 \times 30$-cm bark sample was cut on the north side of the tree at breast height. If a tree still retained needles, denoting recent mortality, a tree-climber also collected bark samples at diameters of $80 \mathrm{~cm}$, $60 \mathrm{~cm}, 40 \mathrm{~cm}$, and $20 \mathrm{~cm}$ up the bole. Each sample was examined for bark beetles and their galleries, and beetles were identified to species. Trees with signs of bark beetle attack and $<75 \%$ crown fade would likely not die and had successfully pitched out attacking beetles, making it unfeasible to determine which species of beetle had made the initial attack.

\section{Dwarf Mistletoe Assessment}

Dwarf mistletoe infection was assessed using the Hawksworth 6-class dwarf mistletoe rating (DMR) (Hawksworth 1977). The procedure divides a tree canopy into thirds and assigns a rating based on presence of mistletoe. If a third has no dwarf mistletoe it is given a rating of $0,<50 \%$ of the branches infected a 1 , and $>50 \%$ a 2 . The 3 values are then summed to provide a dwarf mistletoe rating of $0-6$ for the tree. Average DMR was calculated by averaging the infected and noninfected trees on a plot. DMR for each site is an average of each plot's rating.

\section{Results}

The Barney Springs site had the highest basal area, $24.94 \mathrm{~m}^{2} \cdot \mathrm{ha}^{-1}$, followed by the untreated dense site (Table 1). The Barney Springs site had a high number of both large old-growth trees and small-diameter trees, contributing to the high basal area findings (Fig. 3). The high levels of ingrowth at the Barney Springs site also substantially reduced the quadratic mean diameter (QMD) (Table 1).

\section{Bark Beetle Activity}

Bark beetle evidence was found at each of the 3 sites. The seed-tree site had the highest overall level of activity, with $13.8 \%$ of the trees attacked. The Barney Springs site had 12.4\% of all trees attacked, and the untreated dense site had the least overall bark beetle activity at $1.5 \%$. Across all sites, beetles had a preference for trees $51-60 \mathrm{~cm}$ in diameter (Fig. 3). Although evidence of bark beetles was found at each site, mortality induced by bark beetles was found only at Barney Springs, where 2\% of the trees were killed.

We found evidence of 5 species of bark beetles at the Barney Springs site. These include Ips pini (Say), Dendroctonus brevicomis LeConte, Dendroctonus frontalis Zimmermann, Dendroctonus approximates Dietz, and Dendroctonus valens LeConte. When bark beetle- 


\section{A Barney Springs Diameter Distribution}

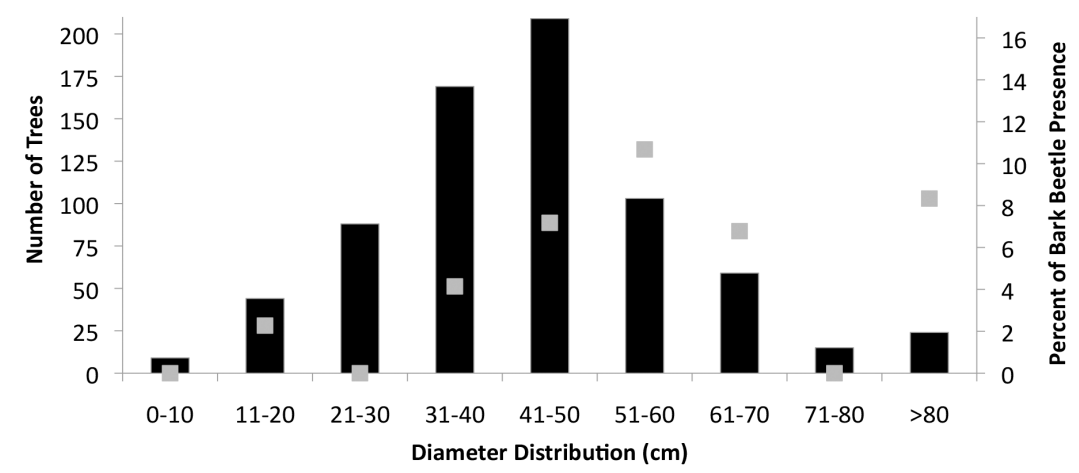

\section{B Seed-Tree Site Diameter Distribution}
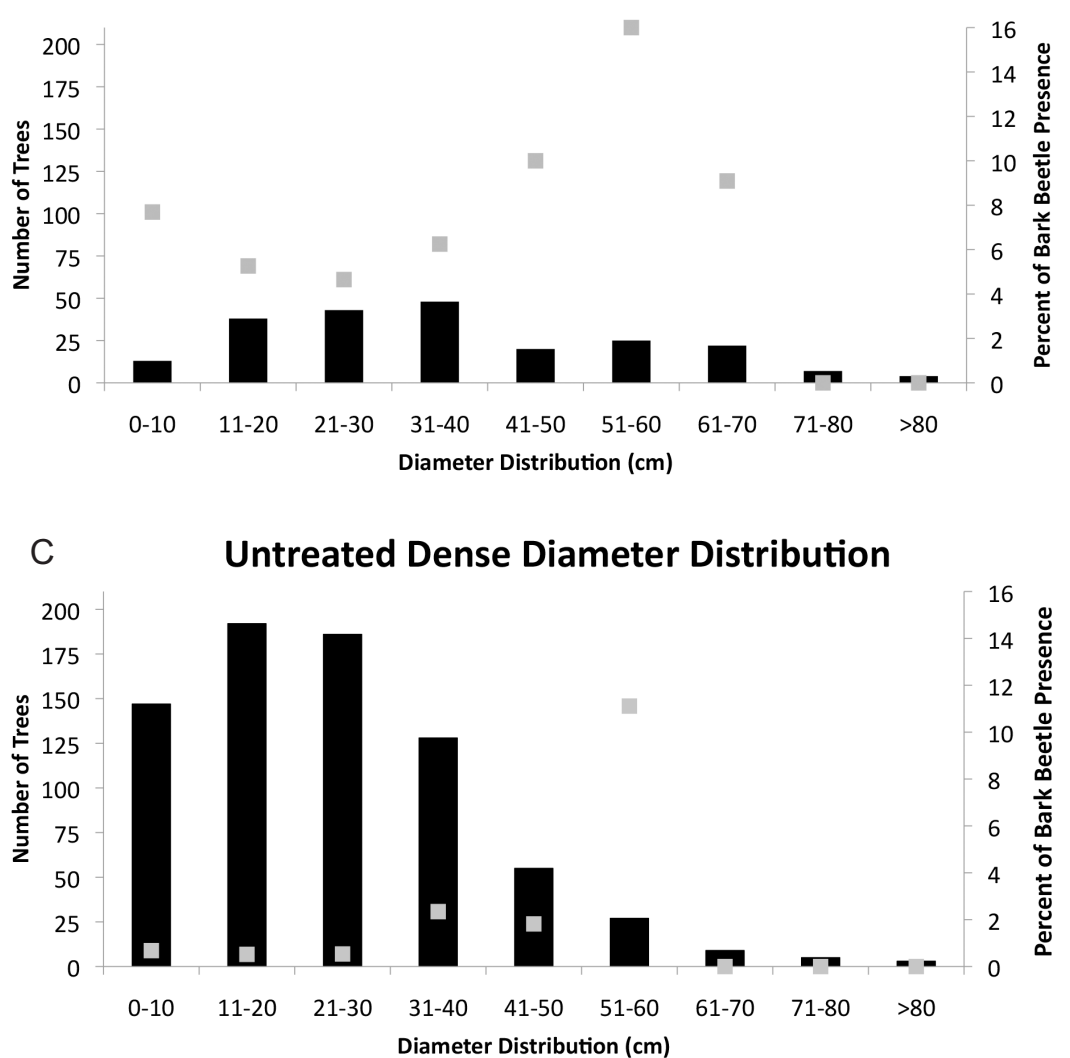

Fig. 3. Number of trees per hectare (black bars) and percentage of trees with bark beetle activity (gray squares) by diameter distribution (in 10-cm classes) for each site: A, Barney Springs Site; B, Seed-Tree Site; C, Untreated Dense Site.

induced mortality was found, D. brevicomis and $D$. frontalis were the most common cause. Ips lecontei Swaine and Ips calligraphus (Germar) were potentially identified, but due to excessive wood borer activity in the samples, gallery identification was not definitive.

\section{Dwarf Mistletoe Activity}

As a function of the overstory species composition, comprised nearly exclusively of ponderosa pine, southwestern dwarf mistletoe was the only mistletoe observed in the 


\section{Percent of Dwarf Mistletoe Infected Trees Across Diameter Classes}

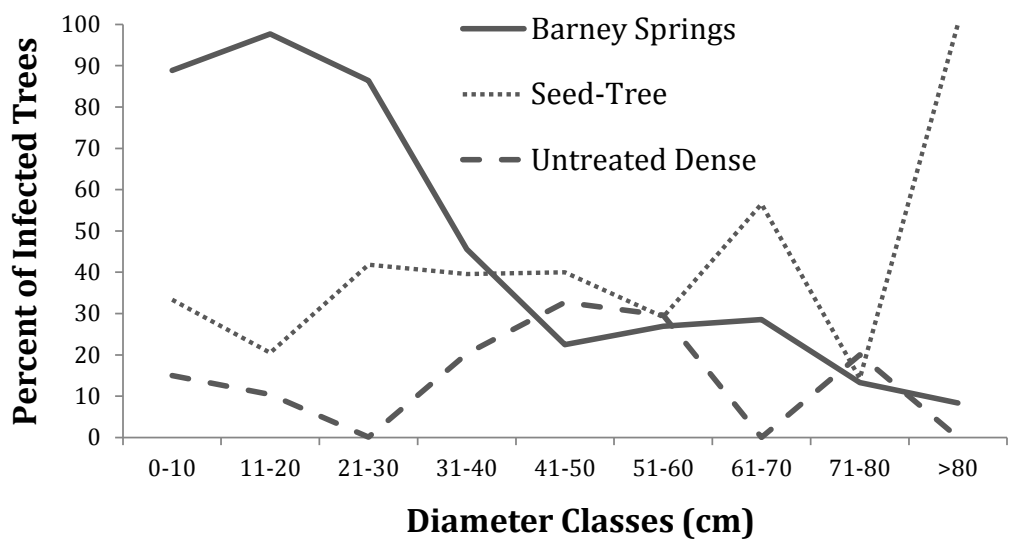

Fig. 4. The percentage of infected trees across diameter classes at the 3 study sites.

study plots. The seed-tree site had the highest percentage of infected trees followed by the Barney Springs site, $37.8 \%$ and $29.1 \%$, respectively. The average DMR rating across the 3 sites is reported as 1.7 at the seed-tree site, 1.3 at the untreated dense site, and 1.2 at Barney Springs. Fig. 4 displays the distribution of dwarf mistletoe-infected trees across diameter classes at the 3 sites. There was not a direct correlation between a tree's dwarf mistletoe infection and beetle attack (Barney Springs: $\mathrm{R}^{2}=0.005$; seed-tree: $\mathrm{R}^{2}=0.106$; untreated dense: $\mathrm{R}^{2}=0.0008$ ).

\section{Discussion}

A historic reconstruction of stand conditions of the Barney Springs site illustrates large density increases, up nearly $600 \%$ since 1883 (Schneider 2012). The reported QMD in Table 1 shows similar values between the Barney Springs and seed-tree sites. This comes as a surprise after a visual inspection of the sites, because Barney Springs clearly has larger trees-a testament to the high levels of ingrowth at the Barney Springs site bringing the QMD down. Also reported by Schneider (2012) is a reconstructed 1883 basal area of $7.97 \mathrm{~m}^{2} \cdot \mathrm{ha}^{-1}$. We found the current basal area of Barney Springs to be $24.94 \mathrm{~m}^{2}$. $\mathrm{ha}^{-1}$, which is another substantial increase compared to the historic conditions. Other studies in northern Arizona report current basal area values ranging from 18 to $28 \mathrm{~m}^{2}$. $\mathrm{ha}^{-1}$ (Covington and Moore 1994, Fulé et al. 1997). We feel these resource-strained conditions are contributing to the moderate level of dwarf mistletoe infection and greater bark beetle-caused tree mortality observed at the Barney Springs site. Although the dense site may also be resource limited, the smallerdiameter trees are not suitable for many of the beetle species present, especially the Dendroctonus beetles (DeMars and Roettgering 1982), and this is perhaps why there was no beetle mortality at this site.

\section{Bark Beetle Activity}

Endemic bark beetle populations are difficult to quantify because of their high variability in space and time. A local entomologist and bark beetle expert qualitatively reports bark beetle-induced mortality around $1 \%$ on average (Hofstetter personal communication). A study conducted on nearby ponderosa stands found only 16 out of 2136 trees sampled $(0.75 \%)$ to have evidence of bark beetles (Sánchez-Martínez and Wagner 2002). We report beetle-induced mortality at $2 \%$ at the Barney Springs site, and $0 \%$ at the seed-tree and untreated dense sites over a 3-year period. We found beetle activity (evidence such as pitch tubes, frass, and/or galleries under the bark) on $12.4 \%$ and $13.8 \%$ of all trees at Barney Springs and the seed-tree sites, respectively. This difference between beetle activity 
and mortality has to do with the fact that numerous bark beetles are required to overcome a tree's defenses to cause mortality. The mere presence of beetles at a site does not translate into greater mortality. It is important to note that pine engraver (Ips pini) presence at Barney Springs may be slightly higher than reported. This is attributed to the difficulty of assessing the upper portions of a tree. Ips pini typically attacks the upper bole (Fischer 1980, Coulson 1984, Kolb et al. 2006). Such attacks are particularly difficult to assess due to the exceptionally tall trees on the site, many in excess of $30 \mathrm{~m}$ (Schneider 2012). A study investigating coleopteran species richness in old-growth boreal forests in Finland found differences between managed stands and old-growth stands (Martikainen et al. 2000). They reported significantly higher saproxylic species in old-growth forests. The increase in saproxylic beetles is not a surprise since a defining characteristic of oldgrowth forests is high levels of down woody debris and snags (Harmon and Hua 1991, Martikainen et al. 2000, Siitonen et al. 2000). However, when Martikainen et al. 2000 excluded saproxylic species from the analysis, species assemblages were very similar to our findings. This trend and the findings in the Sánchez-Martínez and Wagner (2002) study match what we observed, where the bark beetle species found at the Barney Springs site closely matched those of the other 2 sites (and the surrounding ponderosa forest).

\section{Dwarf Mistletoe Activity}

The slightly elevated dwarf mistletoe infections $(\sim 38 \%)$ in the seed-tree site may be attributed to selective logging practices (i.e., high-grading) where heavily infected trees were left as seed-trees and uninfected trees were harvested (Long and Smith 2000). Over the past century, highly variable levels of dwarf mistletoe infections have been observed throughout the southwestern region. This is likely due to the qualitative nature of many early reports and variability of infections spatially and temporally (similar to bark beetle). For example, Theodore Woolsey in 1911 reported large areas of Southwestern ponderosa pine forest where $>60 \%$ of the trees were infected (Woolsey 1911); however, in the following sentence he reports Dr. George G. Hedgcock's findings of only a $1 \%-2 \%$ infec- tion rate of ponderosa pine in the Southwest. Subsequent studies present a range of infection from 30\% to 90\% (Korstian and Long 1922, Andrews and Daniels 1960, Heidmann 1983, Maffei and Beatty 1988), but it is generally accepted that one-third of Southwestern ponderosa pine forests are infected, with a high degree of variability.

Mistletoe infections can increase host susceptibility to bark beetle attack (Hawksworth 1961, McCambridge et al. 1982). Although average DMR numbers were not extreme, and the level of mistletoe infection is similar to that found by others (Andrews and Daniels 1960, Maffei and Beatty 1988), we found a trend between the proportion of trees infected per site and the percent of attacked trees with bark beetle activity. However, there was not a direct correlation on a tree-by-tree basis between dwarf mistletoe and bark beetles (Barney Springs: $\mathrm{R}^{2}=0.005$, seed-tree: $\mathrm{R}^{2}=$ 0.106 , untreated dense: $\left.\mathrm{R}^{2}=0.0008\right)$. This lack of correlation likely relates to stand structure (e.g., the availability of large enough trees for bark beetles to attack), which the untreated dense site had a deficit of. For example, the seed-tree site had the highest proportion of infected trees, followed by the Barney Springs site. Although both the seedtree and Barney Springs sites had the highest percentage of dwarf mistletoe-infected trees and the highest percentage of bark beetleattacked trees, there was not a direct correlation between a tree's dwarf mistletoe infection and bark beetle attack (Kenaley et al. 2006, 2008).

In addition to dwarf mistletoe, past management practices such as aggressive fire suppression tactics and grazing can greatly influence tree condition (Mutch et al. 1993, Covington and Moore 1994, Brown and Sieg 1996, Fulé et al. 1997). Starting in the early twentieth century, the primary mechanism for controlling tree establishment was substantially reduced by suppressing fire, leading to stands with high basal areas and high stem densities compared to pre-European settlement. Grazing as a fire suppression technique was effective in preventing the spread of wildfire in grazed stands, which again led to overly dense forest stands. These stand conditions can contribute to increased tree stress that can lead to greater susceptibility to bark beetle attack. 
Utility of Barney Springs for Predicting Old-Growth Restoration Treatment Outcomes

Since Barney Springs has experienced other confounding practices such as fire suppression and grazing, it does not provide an example of a pristine forest. As discussed above, fire suppression has caused a large amount of ingrowth and a basal area much greater than historical records $\left(7.97 \mathrm{~m}^{2} \cdot \mathrm{ha}^{-1}\right.$ vs. $\left.24.94 \mathrm{~m}^{2} \cdot \mathrm{ha}^{-1}\right)$. We only found bark beetle-caused mortality in the ponderosa trees at Barney Springs, likely due to the high basal area of the site, not the fact that it has large decadent trees. Bark beetle activity was highest in the $51-60 \mathrm{~cm}$ diameter class across all 3 sites.

During the Barney Springs inventory, the largest amount of ingrowth was found in the 31$50-\mathrm{cm}$ range. As this cohort approaches the 51-60-cm range, greater bark beetle mortality could occur. An old-growth stand in this region with an unaltered fire regime would not have such a large cohort of young trees, as fire would have greatly reduced tree establishment. This supports the idea that restoration treatments in the ponderosa pine forest type will require continued maintenance to keep tree densities low.

In light of the call for modification in forest management goals that are based upon principles of forest restoration (Reynolds et al. 2013), studies of stands such as Barney Springs can offer valuable information. Even though Barney Springs is not a pristine forest, the limited information on southwestern oldgrowth forests makes it an area of interest. Understanding insect and disease regimes at the Barney Springs site helps elucidate how these disturbances function in large oldgrowth trees. Barney Springs needs major basal area reductions, if for no other reason than to reduce the risk of a stand-replacing fire. If such thinning treatments were conducted, the use of Barney Springs to study old-growth forests would be greatly increased. The information gained from this study helps us understand that old-growth forests that do not have strict upper limits on stand density and basal area are susceptible to tree-killing bark beetle activity.

\section{ACKNOWLEDGMENTS}

Funding for this project was provided by a USDA Forest Service, Forest Health Monitor- ing, Evaluation Monitoring Program Award INT-EM-B-Regional (11-CS-11031600-087).

\section{Literature Cited}

Allen, C.D., M. Savage, D.A. Falk, K.F. Suckling, T.W. Swetnam, T. Schulke, and J.T. Klingel. 2002. Ecological restoration of southwestern ponderosa pine ecosystems: a broad perspective. Ecological Applications 12:1418-1433.

Amman, G.D. 1977. The role of the mountain pine beetle in lodgepole pine ecosystems: impact on succession. Pages 3-18 in W.J. Mattson, editor, The role of arthropods in forest ecosystems. Springer-Verlag, New York, NY.

ANDREwS, S.R., AND J.P. DANIELS. 1960. A survey of dwarf mistletoes in Arizona and New Mexico. USDA Forest Service, Rocky Mountain Forest and Range Experimental Station, Fort Collins, CO.

Axelson, J.N., R.I. Alfaro, and B.C. Hawkes. 2009. Influence of fire and mountain pine beetle on the dynamics of lodgepole pine stands in British Columbia, Canada. Forest Ecology and Management 257: 1874-1882.

BAILEY, J.D., AND W.W. Covington. 2002. Evaluating ponderosa pine regeneration rates following ecological restoration treatments in northern Arizona, USA. Forest Ecology and Management 155:271-278.

BRown, P.M., AND C.H. SiEg. 1996. Fire history in interior ponderosa pine forests of the Black Hills, South Dakota, USA. International Journal of Wildland Fire 6:97-105.

Carpenter, S.E., M.E. Harmon, E.R. Ingham, R.G. Kelsey, J.D. Lattin, and T.D. Schowalter. 1988. Early patterns of heterotroph activity in conifer logs. Proceedings of the Royal Society of Edinburgh 94: 33-43.

Chan-McLeod, A.C.A. 2006. A review and synthesis of the effects of unsalvaged mountain-pine-beetleattacked stands on wildlife and implications for forest management. Journal of Ecosystems and Management 7:119-132.

Coulson, R.N. 1984. Forest entomology: ecology and management. Wiley Pub. Inc., Hoboken, NJ.

Covington W.W., P.Z. Fulé, M.M. Moore, S.C. Hart, T.E. Kolb, J.N. Mast, S.S. SACKETT, and M.R. WAGNER. 1997. Restoring ecosystem health in ponderosa pine forests of the southwest. Journal of Forestry 95:23-29.

Covington, W.W., ANd M.M. Moore. 1994. Post-settlement changes in natural fire regimes and forest structure: ecological restoration of old-growth ponderosa pine forests. Journal of Sustainable Forestry 2:153-181.

Dahms, C.W., AND B.W. GeILS. 1997. An assessment of forest ecosystem health in the Southwest. General Technical Report RM-GTR-295, USDA Forest Service, Rocky Mountain Forest and Range Experimental Station, Fort Collins, CO.

DeMars, C.J., and B.H. Roettgering. 1982. Western pine beetle. Forest Insect and Disease Leaflet 1. United States Department of Agriculture.

Edmonds, R.L., J.K. AgEe, and R.I. GaRA. 1999. Forest health and protection. McGraw-Hill, Boston, MA.

Fischer, W.C. 1980. Prescribed fire and bark beetle attack in ponderosa pine forests. Fire Management Notes 41:10-12. 
Fulé, P.Z., W.W. Covington, and M.M. Moore. 1997. Determining reference conditions for ecosystem management of southwestern ponderosa pine forests. Ecological Applications 7:895-908.

Goheen, D.J., And E.M. Hansen. 1993. Effects of pathogens and bark beetles on forests. Pages 175196 in T. Schowalter and G. Filip, editors, Beetlepathogen interactions in conifer forests. Academic Press, London.

Harmon, M.E., and C. Hua. 1991. Coarse woody debris dynamics in two old-growth ecosystems. BioScience 41:604-610.

Harrington, M.G., and F.G. Hawksworth. 1990. Interactions of fire and dwarf mistletoe on mortality of southwestern ponderosa pine. Pages 234-240 in J.S. Krammes, technical coordinator, Effects of fire management of southwestern natural resources. Proceedings of symposium; 1988 Nov. 15-17; Tucson, AZ. GTR RM-191, USDA Forest Service, Rocky Mountain Forest and Range Experimental Station, Fort Collins, CO.

Hawksworth, F.G. 1961. Dwarf mistletoe of ponderosa pine in the Southwest. No 1246, USDA Forest Service, Rocky Mountain Forest and Range Experimental Station, Fort Collins, CO. 112 pp.

Hawksworth, F.G. 1977. The 6-class dwarf mistletoe rating system. RM-GTR-48, USDA Forest Service, Rocky Mountain Forest and Range Experimental Station, Fort Collins, CO.

Hawksworth, F.G., and D. Wiens. 1996. Dwarf mistletoes: biology, pathology, and systematics. Agriculture Handbook 709, USDA Forest Service, Washington, DC.

Hawksworth, F.G., J.C. Williams-Cipriani, B.B. EaV, B.W. Geils, R.R. Johnson, M.A. Marsden, J.S. Beatty, and G.D. Shubert. 1992. Interim dwarf mistletoe impact modeling system: users guide and reference manual. Report MAG-91-3, USDA Forest Service, Fort Collins, CO.

Heidmann, L.J. 1983. Silvicultural control of dwarf mistletoe in southwestern ponderosa pine. RM-RN433, USDA Forest Service, Rocky Mountain Forest and Range Experimental Station, Fort Collins, CO.

Kenaley, S.C., R.L. Mathiasen, and C.M. Daugherty. 2006. Selection of dwarf mistletoe-infected ponderosa pines by Ips species (Coleoptera: Scolytidae) in northern Arizona. Western North American Naturalist 66:279-284.

Kenaley, S., R.L. Mathiasen, and E.J. Harner. 2008. Mortality associated with a bark beetle outbreak in dwarf mistletoe-infested ponderosa pine stands in northern Arizona. Western Journal of Applied Forestry 23:113-120.

Klemmedson, J.O. 1976. Effect of thinning and slash burning on nitrogen and carbon in ecosystems of young dense ponderosa pine. Forest Science 22: $45-53$.

Kolb, T.E., N. Guerard, R.W. Hofstetter, and M.R. WAGNER. 2006. Attack preference of Ips pini on Pinus ponderosa in northern Arizona: tree size and bole position. Agricultural and Forest Entomology 8:295-303.

Kolb, T.E., M.R. Wagner, and W.W. Covington. 1994. Concepts of forest health. Journal of Forestry 92:10-15.

KopLIN, J.R. 1969. The numerical response of woodpeckers to insect prey in a subalpine forest in Colorado. Condor 71:436-438.
Konstian, C.F., And W.H. Long. 1922. The western yellow pine dwarf mistletoe: effect on growth and suggestions for control. USDA Bulletin 1112.

Long, J.N., AND F.W. Smith. 2000. Restructuring the forest: goshawks and the restoration of southwestern ponderosa pine. Journal of Forestry 98:25-30.

Madany, M.H., AND N.E. WEST. 1983. Livestock grazingfire regime interactions within montane forests of Zion National Park, Utah. Ecology 64:661-667.

MafFei, H., AND J. BEatTy. 1988. Changes in the incidence of dwarf mistletoe over 30 years in the Southwest. Pages 88-90 in Proceedings of the Thirty-Sixth Annual Western International Forest Disease Work Conference, Park City, Utah, 19-23 September 1998.

Martikainen, P., J. Siitonen, L. Kaila, P. Punttila, and J. RauH. 1999. Bark beetles (Coleoptera, Scolytidae) and associated beetle species in mature managed and old-growth boreal forests in southern Finland. Forest Ecology and Management 116:233-245.

Martikainen, P., J. Sittonen, P. Punttila, L. Kaila, and J. RAUH. 2000. Species richness of Coleoptera in mature managed and old-growth boreal forests in southern Finland. Biological Conservation 94:199-209.

McCambridge, W.F., F.G. Hawksworth, C.B. Edminster, AND J.G. LaUt. 1982. Ponderosa pine mortality resulting from a mountain pine beetle outbreak. Research Paper RM-235, USDA Forest Service, Rocky Mountain Forest and Range Experiment Station, Fort Collins, CO. dx.doi.org/10.5962/bhl .title.98611

McHugh, C.W., T.E. KolB, AND J.L WiLsOn. 2003. Bark beetle attacks on ponderosa pine following fire in northern Arizona. Environmental Entomology 32: 510-522.

Moore, M.M., D.W. Huffman, P.Z. Fulé, W.W. CovingTON, AND J.E. CRouse. 2004. Comparison of historical and contemporary forest structure and composition on permanent plots in southwestern ponderosa pine forests. Forest Science 50:162-176.

Mutch, R.W., S.F. Arno, J.K. Brown, C.E. Carlson, R.D. OtTmar, and J.L. Peterson. 1993. Forest health in the Blue Mountains: a management strategy for fire-adapted ecosystems. PNW-GTR-310, USDA Forest Service, Pacific Northwest Research Station, Portland, OR.

Parks, C.G., E.L. Bull, R.O. Tinnin, J.F. Shepherd, and A.K. Blumton. 1999. Wildlife use of dwarf mistletoe brooms in Douglas-fir in northeast Oregon. Western Journal of Applied Forestry 14:100-105.

Rasmussen, L.A., G.D. Amman, J.C. Vandygriff, R.D. OAKEs, A.S. Munson, And K.E. Gibson. 1996. Bark beetle and wood borer infestation in the Greater Yellowstone area during four post-fire years. INTRP-487, USDA Forest Service, Rocky Mountain Forest and Range Experiment Station, Ogden, UT.

Reynolds, R.T., A.J. Sanchez Meador, J.A. Youtz, T. NicoLet, M.S. Matonis, P.L. Jackson, D.G. DeLorenzo, AND A.D. Graves. 2013. Restoring composition and structure in Southwestern frequent-fire forests: a science-based framework for improving ecosystem resiliency. General Technical Report RMRSGTR-310, USDA Forest Service, Rocky Mountain Research Station, Fort Collins, CO.

Roe, A., and G. Amman. 1970. Mountain pine beetle in lodgepole pine forests. INT-RP-71, USDA Forest Service, Rocky Mountain Forest and Range Experiment Station, Ogden, UT. 
SÁNChez-MarTínez, G., AND M.R. Wagner. 2002. Bark beetle community structure under four ponderosa pine forest stand conditions in northern Arizona. Forest Ecology and Management 170:145-160.

Santoro, A.E., M.J. Lombardero, M.P. Ayres, and J.J. RuEL. 2001. Interactions between fire and bark beetles in an old growth pine forest. Forest Ecology and Management 144:245-254.

SCHNEIDER, E. 2012. Reference conditions of historical changes in an unharvested ponderosa pine stand: implications for forest health. Master's thesis, Northern Arizona University, Flagstaff, AZ.

Sittonen, J., P. Martikainen, P. Punttila, and J. Rauh. 2000. Coarse woody debris and stand characteristics in mature managed and old-growth boreal mesic forests in southern Finland. Forest Ecology and Management 128:211-225.

Stark, R.W. 1982. Generalized ecology and life cycles of bark beetles. Pages 21-45 in J.B. Mitton, and K.B. Sturgeon, editors, Bark beetles in North American conifers: a system for the study of evolutionary biology. University of Texas Press, Austin, TX.

Stone J.E., T.E. Kolb, and W.W. Covington. 1999. Effects of restoration thinning on presettlement Pinus ponderosa in northern Arizona. Restoration Ecology 7:172-182.

USDA FoREst SERVICE. 1995. Terrestrial ecosystem survey Coconino National Forest. USDA Forest Service Region 3, Albuquerque, NM.
WaLlin, K.F., T.E. Kolb, K.R. Skov, and M.R. Wagner. 2004. Seven-year results of thinning and burning restoration treatments on old ponderosa pines at the Gus Pearson Natural Area. Restoration Ecology 12: 239-247.

Waltz, A.E., P.Z. Fulé, W.W. Covington, and M.M. Mooke. 2003. Diversity in ponderosa pine forest structure following ecological restoration treatments. Forest Science 49:885-900.

Watson, D.M. 2001. Mistletoe-a keystone resource in forests and woodlands worldwide. Annual Review of Ecology and Systematics 32:219-249.

Western Regional Climate Center. 2013. Munds Park, AZ (025780) from 1986-2013. http://www.wrce .dri.edu/cgi-bin/cliMAIN.pl?az5780

Woolsey, T.S. 1911. Western yellow pine in Arizona and New Mexico. Bulletin 101, USDA Forest Service.

Zausen, G.L., T.E. Kolb, J.D. Bailey, and M.R. Wagner. 2005. Long-term impacts of stand management on ponderosa pine physiology and bark beetle abundance in northern Arizona: a replicated landscape study. Forest Ecology and Management 218:291-305.

Received 13 November 2014 Accepted 15 June 2015 